Buy Instant PDF Access

Qty:

$\$ 37.50$

- $\quad \underline{\text { Sample PDF }}$

Available In

- Advances in Media, Entertainment, and the Arts

- InfoSci-Books

- InfoSci-Media and Communications

- InfoSci-Social Sciences and Humanities

- InfoSci-Select

- $\quad$ InfoSci-Social Sciences Knowledge Solutions - Books

\title{
Rethinking the Role of Traditional Media on Migration Issues in Nigeria
}

Gideon Ibukuntomiwa Folorunso (Covenant University, Nigeria), Adeola I. Oyeyemi (Covenant University, Nigeria), Oluwakemi D. Udoh (Covenant University, Nigeria), Olaniyi T. Ayodele (Covenant University, Nigeria) and Nchekwube O. Excellence-Oluye (Covenant University, Nigeria)

Source Title: Handbook of Research on the Global Impact of Media on Migration Issues

Copyright: (C) 2020 |Pages: 11

DOI: 10.4018/978-1-7998-0210-5.ch006

OnDemand PDF Download:

$\$ 37.50$

\section{Abstract}

Traditional media is widely embraced by both the literate and illiterate population in different countries. Despite the wide coverage and acceptability of the traditional media in Nigeria, it has not favourably promoted migration issues, which has constituted national image crisis on an international scale. The media, having usually promoted their works with the mantra "voxidei, voxipopuli", is thus burdened with the duty to liberate the masses by speaking truth to power, anything short of which is mere patronage of the people and contrary to the fundamental duties of the media as citizens of the world. This chapter also adopts secondary source of data collection and a content analysis model to analyse the data gathered, while the analysed data is 
presented in a narrative approach. The major finding of this book chapter is that, the known traditional media houses are playing around politics and money, bringing to life the saying that he who pays the piper dictates the tune, and this has in turn led to the continuance of illegal and dehumanising activities around the national borders of the country.

Chapter Preview

$\underline{\text { Top }}$

\section{Introduction}

The media is a wide platform for airing opinions, facts and investigations on issues with communal interests while shaping the mind-set of the targeted audience towards a particular direction (Triandafyllidou, 2017, pp. 1-2). The reality of migration issues and the citizens are at the moment tangential to policy makers and the media. Migration cannot be totally viewed as being negative, howbeit; traditional media reduces its importance by linking it majorly to issues of terrorism, crime and racial discrimination. This trend, coupled with the interests of media stakeholders (such as the government and owners of media corporations), tends to limit the creativity of traditional media journalists and thus, opens the pathway for new media to thrive (Triandafyllidou, 2017).

Recently, undocumented migration (which some refer to as irregular migration in recent nationstate setting) is a typical African survival instinct, due to the state of leadership inter alia within the continent. However, ancient and medieval history has a differing opinion - that migration is not limited to scouting for greener pastures and more importantly, it is not peculiar to Africans. The nexus between immigration and crime is conspicuously aired and promoted, while the media subterfuges positive news with regards to immigration.

With the increasing influx of people from less developed countries to developed countries, the media remains the fundamental source - not the only source - and channel of information about migrant activities, through migration journalism due to its largest share of citizens patronage. This underpins the importance of traditional media outfits as the shaper of citizens' perception on any social phenomenon or activity. To do this, the press, the radio, television, etc. are greatly engaged. Whatever the media sells as information on migration, can either discourage or accredit individuals' decision on movement across international borders. Migrants also subscribe to local traditional media for the purpose of learning about their new location. In addition, expectations, perceptions and aspirations of migrants are shaped by the activities of these media outfits in various capacities. While perception, beliefs and attitude about migration are based on personal experiences and the experiences of those portrayed in the media, they serve as opinion shapers to both the migrants and the host nations, creating a form of positivity or negativity, as the case may be (Allen, Blinder and McNeil, 2017).

In a world of capitalism, the media environment has been commercialised and monetised, hence, business comes first. The economic motivation behind a story is what drives it to air, for the purpose of attracting the targeted readers and/or listeners. Allen et al. (2017) believe that beyond these reasons, social and cultural leanings also come in handy to influence the contents. In particular, policymakers and advocates have dominated the space of migration journalism as 
stakeholders, at the exclusion of consumers, migrants and the labour force, thus further delineating the scope of traditional media on migration issues.

Triandafyllidou (2017) posits that, another aspect is the politicisation and monetisation of the media. Like every other sector, once the media is involved with political advertisement and promotion for its profit purposes, it is rightly labelled partisan (aligned with the political elites or parties), thus the language used in engaging their audience in political discourse is subtle or neutral. To uphold a non-existent national image, local traditional media negatively influences the content of what is aired by focusing on the actions of migrants and not on the causal factors of migration, such as the political economy and the socio-cultural milieu of the country.

\section{Complete Chapter List}

Search this Book:

Reset

Table of Contents

View Full PDF

Detailed Table of Contents

View Full PDF

Preface

Juliet Wambui Macharia

View Full PDF

Chapter 1

Public Broadcasting and Migration: Media Representation of Turkish "Guest Workers" in

Germany (pages 1-20)

Mehmet Fatih Çömlekçi

Sample PDF

$\$ 37.50$

Chapter 2

Terrific Experiences, Receptiveness, and Mediatic Representation of Migration in the Global

Community (pages 21-38)

Jegede Ebenezer Ajibade

Sample PDF

$\$ 37.50$

Chapter 3

M Stands for Media, Migration, and Modern Slavery in the UK (pages 39-47)

Nelson Okorie, Suleimanu Usaini

Sample PDF

$\$ 37.50$

Chapter 4

African Migrant Narratives, Modern Slavery, and Human Rights Violations in Libya (pages 48-

67)

Lady Adaina Ajayi, Anijesushola O. Ajayi, Sheriff F. Folarin, Abdulrahman Oluwaseyi Tiamiyu, Chioma Eucharia Nnajidema, Oluwaseyi Emmanuel Ogunnowo

Sample PDF

$\$ 37.50$ 
Chapter 5

Media's Role in Communicating Gender and Migration Messages in Africa (pages 68-84)

Juliet Wambui Macharia

Sample PDF

$\$ 37.50$

Chapter 6

Rethinking the Role of Traditional Media on Migration Issues in Nigeria (pages 85-95)

Gideon Ibukuntomiwa Folorunso, Adeola I. Oyeyemi, Oluwakemi D. Udoh, Olaniyi T. Ayodele,

Nchekwube O. Excellence-Oluye

$\underline{\text { Sample PDF }}$

$\$ 37.50$

Chapter 7

Media, the Family, and Human Trafficking in Nigeria (pages 96-114)

Stellamaris Ngozi Okpara

$\underline{\text { Sample PDF }}$

$\$ 37.50$

Chapter 8

Channels Television on YouTube: Shaping the African Discourse on Migration (pages 115-141)

Oluwafolafunmi Omoladun Afolabi, Tolulope Kayode-Adedeji, Evaristus Adesina, Babatunde

Adeyeye, Suleimanu Usaini, Nelson Okorie

Sample PDF

$\$ 37.50$

Chapter 9

Role of the Media on Migrants' Vulnerability to Health Hazards (pages 142-156)

Olayinka Susan Ogundoyin

Sample PDF

$\$ 37.50$

Chapter 10

Malevolent Trespassers or Benevolent Guests: A Meta-Analysis of Media Representation of

African Migrants (pages 157-179)

Dickson Oluwasina Ogunkunle, Babatunde Raphael Ojebuyi

Sample PDF

$\$ 37.50$

Chapter 11

Human Rights Abuses Against Internally Displaced Persons (IDPs) in Nigeria: Investigating

Media Reportage (pages 180-200)

Stephen Damilola Odebiyi, Olugbenga Elegbe

Sample PDF

$\$ 37.50$

Chapter 12

The Mass Media, Migration Issues, and the Brain Drain Nexus: Implications for Political

Development in 21st Century Nigeria (pages 201-221)

Esther Fadeke Olu-Owolabi, Ikedinachi Ayodel Power Wogu, Adigwe Felix Azogu, Happiness

Onyemaechi Emmanuel, Agnes Ezeji, Sanjay Misra, Uchenna Kingsley Ogbuehi

Sample PDF

$\$ 37.50$ 
Chapter 13

Newspaper Coverage of Internal Youth Migration in Nigeria (pages 222-234)

Chinyere Azuka Mbaka, Onyinyechi Nancy Nwaolikpe

Sample PDF

$\$ 37.50$

Chapter 14

Risk Communication for Viral Hepatitis Management Among Migrants (pages 235-252)

Evaristus Adesina, Olusola Oyero, Nelson Okorie, Charity Ben-Enukora, Babatunde Adeyeye

Sample PDF

$\$ 37.50$

Chapter 15

Media Advocacy: A Strategy for Addressing Health Concerns in Internally Displaced Persons

(IDPs) Camps in Nigeria (pages 253-271)

Faith O. Olanrewaju, Tayo George, Olaniyi T. Ayodele, Adekunle O. Olanrewaju

Sample PDF

$\$ 37.50$

Chapter 16

Media Hype, Greener Pastures Syndrome, and Migration in Nigeria (pages 272-292)

Adeola Obafemi Mobolaji, Babatunde Raphael Ojebuyi

Sample PDF

$\$ 37.50$

Chapter 17

Predicting Migration to Developed Countries: The Place of Media Attention (pages 293-311)

Mutiu Iyanda Lasisi, Rasheed Ademola Adebiyi, Umar Olansile Ajetunmobi

Sample PDF

$\$ 37.50$

Chapter 18

Media and the Challenges of Displaced Men in Nigeria: A Case Study of Durumi Area One IDPs

Camp, Abuja, FCT (pages 312-330)

Felix Chidozie Chidozie, Augustine Ejiroghene Oghuvbu

Sample PDF

$\$ 37.50$

Copyright (C) 1988-2020, IGI Global - All Rights Reserved 